\title{
The Effect of Problem-Solving Model to Improve Communicating Skills and Mastery Concept in Chemistry
}

\author{
Ratu Betta Rudibyani \\ Department of Chemistry, Teacher Training and Education Faculty \\ Universitas Lampung \\ Bandar Lampung, Indonesia \\ Ratu.betta.r@gmail.com
}

\begin{abstract}
This research was aimed to describe the effects of problem-solving models to improve Communicating Skills and mastery of students' Chemistry concepts. This research using a quasi-experimental method with Non-Equivalence PretestPosttest Control Group Design. The sample was obtained by cluster random sampling technique. Effectiveness is evidenced by the improvement of communicating skills and mastery of students' Chemistry concepts which is supported by a test of influence. The results of the study obtained that communicating skills and mastery of students' Chemistry concepts was high and have a large measure of influence with problem-solving models. The average value of $n$-Gain skills in communicating and mastering students' concepts in the experimental class is 0.71 with high criteria and the control class is 0.30 with low criteria. The average result of the experimental class size effect calculation for the experimental class is 0.94 with large criteria and the control class is 0.70 with moderate criteria. The conclusions of this study were problem-solving model have a great influence in improving communicating skills and mastery of students' Chemistry concepts.
\end{abstract}

Keywords- problem-solving; communicating skills; chemistry concepts

\section{INTRODUCTION}

Chemistry is one part of the science that studies the structure, composition, properties, and changes of matter and also an energy that accompany the materials change and reasoning skills of students [1]. The chemistry is the science of searching for answers to the questions of what, why, and how natural phenomena relating to the composition, structure, and properties change, dynamics, and energetics substance. There are two issues related to chemistry inseparable, that chemistry as the products (knowledge of chemistry in the form of facts, concepts, principles, laws, and theories) and chemistry as the process (scientific work). Therefore, the learning of chemistry and assessment of chemistry learning should consider the characteristics of chemistry as process and product [2].

Chemistry as the process includes a way of thinking, attitudes, and scientific activity steps to obtain the products of chemistry. From discovering the problem, gather the facts related to the problem, making assumptions, controlling variables, make observations, take measurements, make predictions, collect and process data observation, as well as summarize and communicate.

Chemistry as the product can be law, concept, postulate, and theory. While the chemistry values associated with moral responsibility, social values, attitudes and actions of a person in learning or developing chemistry. Attitudes and actions, for example, curiosity, honesty, thoroughness, diligence, caution, tolerant, and saving [3].

Communicating skills is one of the science process skills. Basic science process skills were six among others observing, classifying, measure, predict, summarize and communicate. Skills convey something orally and in writing, including communicating [4].

Judging from the material, in studying chemistry not only requires an understanding and mastery of concepts alone but in studying chemistry here students are actively together with teachers apply the knowledge learned into the development of the self [5]. Chemistry lesson needs to be taught for the specific objective that is to equip students knowledge, understanding, and a number of skills required to enter higher education and develop science and technology. Learning chemistry emphasizes a direct learning experience through the development and process skills and scientific attitude so that such a study is requiring a special learning.

Based on observations and interviews with teachers of chemistry, on the learning process chemistry, students can't be achieve the expected competencies and can't build their own learning concepts. In addition, students can not solve problems in everyday life related to learning materials, students are not able to find data that can be used to solve the problem, so that students can not set a temporary answer and test the temporary answer, students can not draw conclusions on the matter faced, students are not trained to be able to communicate in learning. As a result, passive students in learning, students' ability to communicate is low, so that the value of student learning outcomes was low.

Learning model that can make students active and can develop the skills to communicate, is a model of Problem Solving. 
Past research has been done, including research Frida says that students' learning ability by using a model of learning Problem-Solving was an increase compared with the conventional model on the lesson of electrolyte and nonelectrolyte solution [6]. In addition, research of Yusi which showed that problem-solving learning was effective to improve students' ability to communicate in the acid-base material [7]. Siti in the study concluded that the problemsolving model was effective in enhancing the ability to conclude in the lesson of electrolyte and non-electrolyte solution [8]. On the basis of the studies, this research studied the model of problem-solving to solve the above problem.

Problem-solving learning model has characteristics that learning begins with the provision of the problem. After that, the students find data or information that can be used to solve the problem. The next stage, students create a temporary answer to the problems, which put forward the hypothesis. Next, the students will prove the truth of the temporary answer. At this stage, students will make observations, experiments, assignments, discussions, and others to prove the temporary answers they put forward, that is giving reasons for the answers made. The last stage is to make conclusions. At this stage, students are required to communicate the results to the other students and provide an explanation of why the students answered that.

On the basis of the above reasoning, in order to increase the ability to communicate and mastery of concepts students, especially on the electrolyte and non-electrolyte solution, then conducted research with the title "Effect of Problem-Solving Learning Models to Improve Communication Skills and Mastery of Students' Chemistry concepts".

\section{EXPERIMENTAL METHOD}

\section{A. Sample and Method}

The method used in this study is a quasi-experiment with pretest-posttest non-equivalent control group design. The study population was all students of class X of SMAN 1 Bandar Lampung consisting of 4 classes. Based on these populations have taken two classes that will be used as a sample. The sampling technique used in this study is a cluster random sampling technique, so that obtained a sample that is the class of X-1 as the experimental class and the class of X-3 as the control class.

\section{B. Collecting Data}

Data used in this study are primary data that is data of pretest and posttest. The independent variable in this study is a model of conventional learning and problem solving, while the dependent variable is the communicating skill and mastery of students' concepts. Learning device used is the syllabus, Lesson plan (RPP), and the Student Worksheet (LKS). The instrument used in this study consisted of pretest and post-test questions in the form of 13 multiple choice questions and 5 essay, student activity sheets and sheets of the teachers' ability Data used in this study are primary data that is data of pretest and posttest. The independent variable in this study is a model of conventional learning and problem solving, while the dependent variable is the communicating skill and mastery of students' concepts. Learning device used is the syllabus, Lesson plan (RPP), and the Student Worksheet (LKS). The instrument used in this study consisted of pretest and post-test questions in the form of 13 multiple choice questions and 5 essay, student activity sheets and sheets of the teachers' ability to manage the learning.

Validity and reliability of 13 multiple choice questions use an ITEMAN application version 4.3. The validity of the test shown by a reliability test while the value is seen from the alpha in Table 1 [9].

TABLE 1. CRITERIA FOR ALPHA

\begin{tabular}{|l|l|}
\hline \multicolumn{1}{|c|}{ The alpha value } & \multicolumn{1}{c|}{ Criteria } \\
\hline 0.81 to 1.00 & Very high \\
From 0.61 to 0.80 & High \\
From 0.41 to 0.60 & Moderate \\
From 0.21 to 0.40 & Low \\
0.00 to 0.20 & Very low \\
\hline
\end{tabular}

Validity and reliability of five essay questions software analyzed with SPSS version 17 for Windows. Problem is said to be valid if the count $r \geq \mathrm{r}$ table the significant level of 5\%. Seen from the reliability test using Cronbach's Alpha reliability degree according to Guilford.

TABLE 2. CRITERIA FOR REABILITY

\begin{tabular}{|l|l|}
\hline \multicolumn{1}{|c|}{ The degree of reliability $(\mathbf{r 1 1})$} & \multicolumn{1}{|c|}{ Criteria } \\
\hline $0.80<\mathrm{r} 11 \leq 1.00$ & Very high \\
$0.60<\mathrm{r} 11 \leq 0.80$ & High \\
$0.40<\mathrm{r} 11 \leq 0.60$ & Moderate \\
$0.20<\mathrm{r} 11 \leq 0.40$ & Low \\
$0.00<\mathrm{r} 11 \leq 0.20$ & Unreliable \\
\hline
\end{tabular}

Influence of problem-solving models in enhancing communication skills and mastery of students' concepts determined with students' achievement as measured by a score of n-gain. The formula is:

$$
\mathrm{n} \text {-Gain }=\frac{\text { posttest score - pretest score }}{\text { maximum score - pretest score }}
$$

According to Hake (in Sunyono, 2014), there are n-Gain criteria [10]:

TABLE 3. N-GAIN CRITERIA

\begin{tabular}{|l|l|}
\hline \multicolumn{1}{|c|}{ Scores n-Gain } & \multicolumn{1}{c|}{ Criteria } \\
\hline n-gain $>0.7$ & High \\
$0.3<$ n-gain $\leq 0.7$ & Moderate \\
n-gain $\leq 0.3$ & Low \\
\hline
\end{tabular}

The effectiveness of problem-solving learning model supported by student activity and teacher's ability to manage a learning. To determine the effectiveness and size of influence (effect size), previously conducted test of normality and homogeneity of the n-Gain value using SPSS version 17 for windows to see the value of sig. 
Test the size of influence (effect size) is used to determine how much influence the treatment of the sample. Before calculating the size of the effect, find the $t$ value obtained from the test independent sample t-test using pretest-posttest value. Calculations the size of the effect (effect size) determine with the formula:

$$
\mu^{2}=\frac{t^{2}}{t^{2}+d f}
$$

$$
\begin{gathered}
\text { Information }: \mu=\text { effect size } \\
t=\mathrm{t} \text { count of the t-test } \\
d f=\text { Degrees of freedom }
\end{gathered}
$$

Criteria according to Dincer [11].

\section{RESULT AND DISCUSSIONS}

\section{A. Validity and Reliability}

Based on calculations that have been performed on the test instrument, then the validity of the test results obtained for the 13 question multiple choice pretest and posttest are presented in Table 4

TABLE 4. THE VALIDITY OF THE QUESTION PRETEST AND POSTTEST, MULTIPLE CHOICE

\begin{tabular}{|l|l|l|}
\hline Question Number & \multicolumn{1}{|c|}{$\sqrt{\alpha}$} & \multicolumn{1}{c|}{ Criteria } \\
\hline 1 & 0.90 & valid \\
2 & 0.93 & valid \\
3 & 0.90 & valid \\
4 & 0.91 & valid \\
5 & 0.91 & valid \\
6 & 0.90 & valid \\
7 & 0.91 & valid \\
8 & 0.91 & valid \\
9 & 0.91 & valid \\
10 & 0.91 & valid \\
11 & 0.91 & valid \\
12 & 0.91 & valid \\
13 & 0.91 & valid \\
\hline
\end{tabular}

Reliability test results to pretest and posttest multiple choice question are presented in Table 5 .

\section{TABLE 5. RELIABILITY PRETEST-POSTTEST MULTIPLE-CHOICE QUESTIONS}

\begin{tabular}{|l|l|l|}
\hline Question Number & \multicolumn{1}{|c|}{$\sqrt{ } \boldsymbol{~ C r i t e r i a ~}$} \\
\hline 1 & 0.94 & Reliable \\
2 & 0.96 & Reliable \\
3 & 0.94 & Reliable \\
4 & 0.95 & Reliable \\
5 & 0.95 & Reliable \\
6 & 0.94 & Reliable \\
7 & 0.95 & Reliable \\
8 & 0.95 & Reliable \\
9 & 0.95 & Reliable \\
10 & 0.95 & Reliable \\
11 & 0.95 & Reliable \\
12 & 0.94 & Reliable \\
13 & 0.95 & Reliable \\
\hline
\end{tabular}

Based on Table 4 and 5, noted that the 13 multiple-choice items have $\sqrt{\alpha}$ value and an alpha value greater than 0.3 so that multiple choice questions as valid and reliable. Test validity to five essay questions is presented in Table 6.

TABLE 6. THE VALIDITY OF THE TEST RESULTS 5 ITEMS PRETEST AND POSTTEST, ESSAY

\begin{tabular}{|l|l|l|l|l|}
\hline $\begin{array}{c}\text { Question } \\
\text { Number }\end{array}$ & r-count & dk & r-table & Criteria \\
\hline 1 & 0.73 & 20 & 0.44 & valid \\
2 & 0.80 & 20 & 0.44 & valid \\
3 & 0.92 & 20 & 0.44 & valid \\
4 & 0.92 & 20 & 0.44 & valid \\
5 & 0.79 & 20 & 0.44 & valid \\
\hline
\end{tabular}

Based on Table 6, the fifth item of the essay has r-count $>$ r-table value, so the question is valid. Reliability test results of the essay are indicated Cronbach's Alpha value of 0.89 , which means overall test instruments categorized as a high degree of reliability.

Based on the analysis of validity and reliability that has been done, it can be concluded that the question of pretest and posttest of communicating skills and mastery of concepts have a valid and reliable. So that used as an instrument of research on the lesson of electrolyte and non-electrolyte solution.

\section{B. Effect of Problem-Solving Models}

Effect of discovery learning model learning can be started by calculating the average value of the average pretest and posttest score in both classes. The average yield of pretest and posttest in both classes is shown in Figure 1.

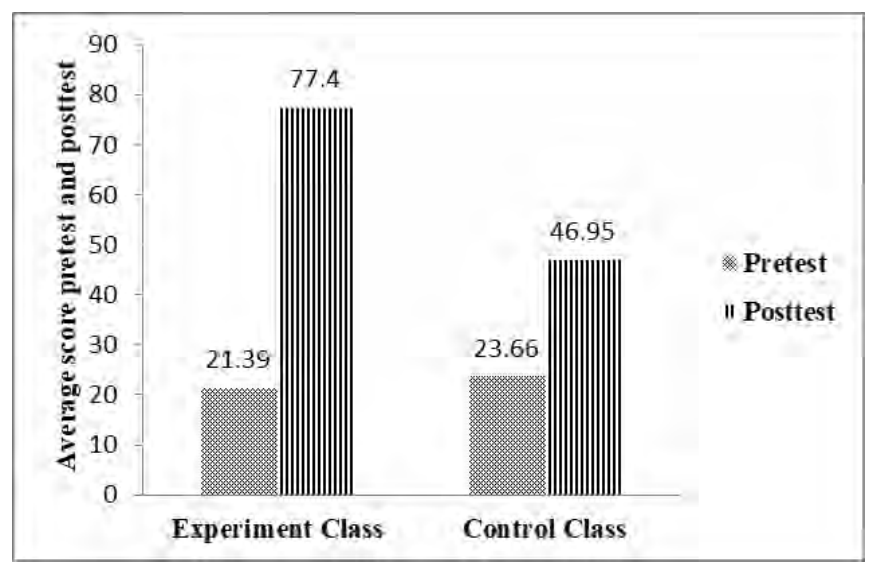

Fig. 1. Average score pretest and posttest of communicating skills and mastery of concepts.

Based on Figure 1, the average students' pretest and posttest score of an experimental class who applied learning model of problem-solving are higher than the average students' pretest and posttest score of control class that applied conventional learning models.

After getting the average value of pretest and posttest, calculated the average value of $n$-Gain between the control 
and the experimental class. The results obtained are shown in Figure 2 .

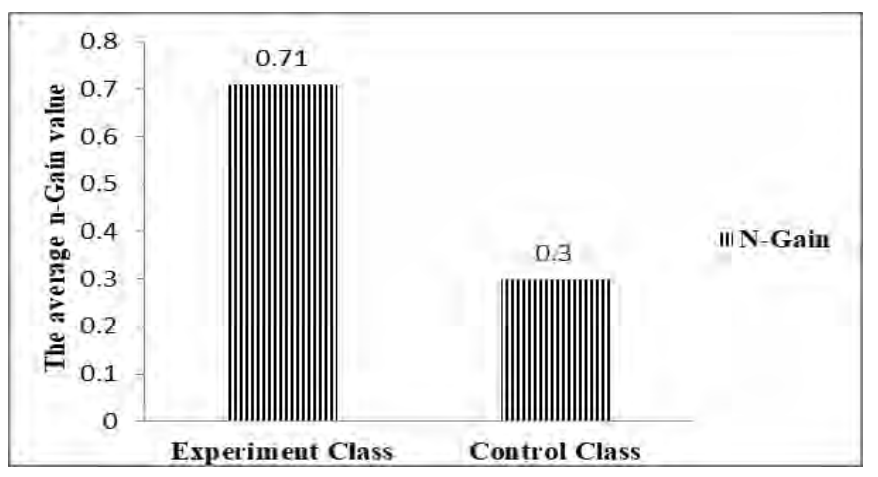

Fig. 2. The average n-Gain value of communication skills and mastery of students' concepts

Based on Figure 2, there is a significant difference in $\mathrm{n}$ Gain value between the control and experiment classes. The average of n-Gain value in the experimental class who applied the problem-solving learning model was higher with the "high" criteria compared to the average of n-Gain value in the control class who applied conventional learning models with "medium" criteria.

It can be concluded that the problem-solving learning model can improve the skills of communication skills and mastery students' concepts on electrolyte and non-electrolyte solution lesson.

This is in line with research Lidiawati which states that the model of problem-solving can improve communication skills and mastery of the concepts on colid.[12].

The effectiveness of problem-solving models in improving the communicating skills and mastery of students' concepts is supported by student activities as shown in table 7 and the ability of teachers to manage the learning shown in Table 7.

\section{TABLE 7. STUDENT ACTIVITY DATA DURING LEARNING}

\begin{tabular}{|c|c|c|c|c|}
\hline \multirow[t]{2}{*}{ Observation Aspect } & \multicolumn{3}{|c|}{$\begin{array}{l}\text { \% Frequency of Student } \\
\text { Activity (in } 3 \text { Meeting) }\end{array}$} & \multirow[t]{2}{*}{ Average } \\
\hline & 1 & 2 & 3 & \\
\hline $\begin{array}{l}\text { Paying attention / listening to } \\
\text { the teacher / friend's } \\
\text { explanation }\end{array}$ & 1,57 & 1,46 & 1,71 & 1,58 \\
\hline Identifying Problems & 4,87 & 2,77 & 4,76 & 4,13 \\
\hline Looking for Information & 3,46 & 4,51 & 4,02 & 4,00 \\
\hline Engaging in Discussion & 4,87 & 6,26 & 8,17 & 6,43 \\
\hline Ask and Answer Questions & 10,69 & 10,33 & 9,88 & 10,30 \\
\hline Submitting Hypothesis & 9,91 & 10,63 & 10,24 & 10,26 \\
\hline Respond to Presentation & 14,62 & 14,56 & 13,66 & 14,28 \\
\hline Proving Hypothesis & 13,68 & 12,66 & 13,29 & 13,21 \\
\hline $\begin{array}{l}\text { Involve yourself in concluding } \\
\text { the discussion results }\end{array}$ & 12,11 & 15,43 & 15,12 & 14,22 \\
\hline $\begin{array}{l}\text { Relevant percentage of student } \\
\text { activity frequency }\end{array}$ & 75,78 & 78,61 & 80,85 & 78,41 \\
\hline Criteria & High & High & $\begin{array}{l}\text { Very } \\
\text { high }\end{array}$ & high \\
\hline $\begin{array}{l}\text { Percentage of irrelevant student } \\
\text { activity frequency }\end{array}$ & 24,21 & 21,40 & 19,55 & 21,59 \\
\hline Criteria & Low & Low & Low & Low \\
\hline
\end{tabular}

Data from student activities at each meeting were taken by observers that is of 10 students as samples. Relevant student activities during the learning process take place is increased. Aspects submit the hypothesis, prove the hypothesis and conclude the results of the discussion at the first meeting have the lowest percentage of frequency, because students are still unfamiliar with the problem-solving learning model, so students are still a few activities during this initial activity and also some students still have difficulty processing words that will be used to submit hypotheses. At the 1-3 meeting, the student activities experienced an increase of $78.41 \%$ of the total average learning time. This means that problem-solving models influence the increase in student activity. This is consistent with the results of Carolin's research that problemsolving can increase student activity and learning achievement [13].

Overall, the average student activity that is relevant to learning with the problem-solving model has a "high" criterion. Use of the problem-solving models makes students actively participate in learning, student activity with the highest percentage of frequency in the part of responding to the percentage of other groups is $14.28 \%$ of the total frequency of time. The average percentage of relevant student activities increased in the second and third meetings and student activities that were irrelevant during the learning process using a problem-solving model decreased from 1-3 views from $21.59 \%$ of total learning time used for irrelevant activities. This is because students have started to get used to learning with problem-solving models when students in the previous learning only listened to the teacher's explanation. Overall student activities that are irrelevant while using problem-solving learning models have a "low" criterion.

TABLE 8. DATA FROM OBSERVATIONS OF THE TEACHER'S ABILITY TO MANAGE THE LEARNING

\begin{tabular}{|l|c|c|c|c|}
\hline \multirow{2}{*}{ Observation Aspect } & \multicolumn{3}{|c|}{$\begin{array}{c}\text { \% Teacher Ability (in 3 } \\
\text { Meeting) }\end{array}$} & \multirow{2}{*}{ Average } \\
\cline { 2 - 4 } & 1 & 2 & 3 & \\
\hline Introduction & 78,12 & 81,25 & 81,25 & 80,20 \\
Problems & 75,00 & 83,33 & 81,25 & 80,55 \\
Search for data & 75,00 & 75,00 & 83,33 & 79,16 \\
Preparing Hypothesis & 75,00 & 75,00 & 87,50 & 79,16 \\
Verify the hypothesis & 84,37 & 78,12 & 87,50 & 80,20 \\
Making conclusions & 72,50 & 77,50 & 78,12 & 78,33 \\
Closing & 81,25 & 87,50 & 85,00 & 85,41 \\
Assessment of Teachers & 77,50 & 80,00 & 82,50 & 80,00 \\
Average & 77,00 & 79,71 & $\mathbf{8 7 , 5 0}$ & $\mathbf{8 0 , 0 0}$ \\
\hline Criteria & High & High & Very & Very \\
& & & high & high \\
\hline
\end{tabular}

Observations data of the teacher's ability to manage the learning were carried out by 2 observers, namely research partners and partner teachers. Aspects observed were introduction, syntax, closing and an assessment of the teacher. Based on the table of observations of the teacher's ability to manage the learning, the results show that the average percentage of teachers' ability to manage the learning from meeting 1 to meeting 3 are increases.

At meeting 1 the ability of teachers to manage learning is still low because students are not used to using problem- 
solving models so that students are not yet conducive when learning, the point is a teacher has not been effective in managing the learning. At meetings 2 and 3 experienced an increase where the teacher was able to manage the learning using problem-solving models. The average percentage of each aspect observed has increased, especially in step 5, that is to conclude. At the last meeting, the teacher was able to apply the problem-solving learning model. Students have been able to follow the problem solving using learning model well where students have been able to learn independently in finding a new concept. The average percentage of teachers' ability to manage the learning is higher.

In addition, students have been able to communicate well and find new concepts independently so that students become more active during the learning process. It can be concluded that the teacher's ability to manage the learning can improve communicating skills and mastery of students' concepts on electrolyte and non-electrolyte solution lesson.

\section{Testing the Hypothesis}

To find out how much effectiveness and size of influence (effect size) then, carried out several tests first namely, normality test and homogeneity test on the average value of nGain. The normality test is done to find out whether the research sample comes from a population that is normally distributed or not. Homogeneity test is conducted to determine whether the research sample has a homogeneous variance or not. The results of normality tests are shown in Table 9.

TABLE 9. THE RESULTS OF THE NORMALITY TEST FOR THE NGAIN VALUE OF THE EXPERIMENTAL CLASS AND CONTROL CLASS

\begin{tabular}{|l|c|c|c|c|}
\hline \multirow{2}{*}{ Class } & \multirow{2}{*}{$\mathbf{N}$} & \multicolumn{2}{c|}{ Sig value } & \multirow{2}{*}{$\begin{array}{c}\text { Criticism } \\
\text { Test }\end{array}$} \\
\cline { 3 - 4 } & & Pretest & Posttest & \multirow{2}{*}{ Sig. $>0.05$} \\
\hline Experiment & 34 & 0.46 & 00.6 & \\
\hline Control & 34 & 0.14 & 0.74 & \\
\hline
\end{tabular}

Based on table 9, shows that the results of the normality test on n-Gain values in the control and experimental classes have sig values from Shapiro-Wilk in the experimental class and control class $>0.05$ so the decision test accepts $\mathrm{H}_{0}$ and rejects $\mathrm{H}_{1}$, which means the research sample comes from a population that is normally distributed. The homogeneity test is shown in Table 10.

TABLE 10. THE HOMOGENEITY TEST RESULTS OF THE N-GAIN VALUE OF THE EXPERIMENTAL CLASS AND CONTROL CLASS

\begin{tabular}{|l|l|l|}
\hline \multicolumn{1}{|c|}{ Value } & \multicolumn{1}{|c|}{ Sig value } & Test Criteria \\
\hline Pretest & 0.08 & Sig.> 0.05 \\
\hline Posttest & 0.63 & \\
\hline
\end{tabular}

Based on table 10, shows that the homogeneity test results on $n$-Gain values in the control and experimental classes have sig values $>0.05$, so the decision accepts $\mathrm{H}_{0}$ and reject $\mathrm{H}_{1}$ means the two samples have homogeneous variances.

\section{The Two Average Difference Test (T-test)}

After testing the normality and homogeneity test, the results showed that the research sample was normally distributed and had a homogeneous variance, then the two average difference test (t-test) could be carried out. The t-test was carried out on the difference in the average n-Gain in the control and experimental classes to determine the effectiveness of the treatment of the research samples shown in Table 11.

TABLE 11. RESULTS OF T-TEST EXPERIMENTAL CLASS AND CONTROL CLASS

\begin{tabular}{|l|l|l|c|}
\hline \multicolumn{1}{|c|}{ Class } & N & Average pretest posttest & $\begin{array}{c}\text { sig. } \\
\text { (2-tailed) }\end{array}$ \\
\hline Experiment & 34 & 21.3977 .40 & .00 \\
\hline Control & 34 & 23.6646 .95 & 0.00 \\
\hline
\end{tabular}

The test criteria, accept $\mathrm{H}_{1}$ if sig. (2-tailed) $<0.05$ and accept $\mathrm{H}_{0}$ if otherwise. Based on Table 10, the results of the two average differences test on the n-Gain value of the skills of communicating and mastering the students' concepts in the experimental class and control class shows that the sig value. (2-tailed) $<0.05$ so that the test decision accepts $\mathrm{H}_{0}$ and rejects $\mathrm{H}_{1}$. The results of this test show that the hypothesis accepts $\mathrm{H}_{0}$ which means that there is a significant difference between the experimental classes using problem-solving learning models with control class who use conventional learning models. In the experimental class, the use of problem-solving models can make students more active and more independent in finding and understanding a concept learned. This is in line with the research of Iqbal which states that the application of problemsolving models can improve the mastery of students' concepts [14]. Seen that the syntax of a problem-solving model can develop students' understanding of concepts.

This test showed that problem-solving learning model used in the experimental class can improve their communicating skills and mastery of students' concept on the lesson of electrolyte and non-electrolyte solution.

\section{E. Influence Size ( Effect Size)}

After knowing how effective the problem-solving learning model is in the experimental class, then calculate of effect size is carried out. Before calculating the influence size, first look for the calculated $t$ value by testing the two average differences on the pretest and posttest values between the control class and the experimental class. $T$ value obtained is used for calculating influence size (effect size) on the communicating skills and mastery of students' concepts on electrolyte and non-electrolyte solution lessons. The effect size on the experiment and control class shown in Table 12.

TABLE 12. RESULT OF EFFECT SIZE

\begin{tabular}{|l|l|l|l|l|l|}
\hline \multicolumn{1}{|c|}{ Class } & \multicolumn{1}{|c|}{$\mathbf{N}$} & \multicolumn{1}{|c|}{$\mathbf{D}$} & \multicolumn{1}{|c|}{ t-count } & $\begin{array}{c}\text { Value of } \\
\text { effect size }\end{array}$ & \multicolumn{1}{c|}{ Criteria } \\
\hline Experiment & 34 & 66 & 22.83 & 0,94 & High \\
\hline Control & 34 & 66 & 8.05 & 0,70 & Moderate \\
\hline
\end{tabular}


Based on the calculation of the effect size value, obtained results that there are differences in the effect of the control class and the experimental class. The effect size value in the experimental class using the problem-solving learning model is greater than the control class that uses conventional learning models. The effect size value in the experimental class is 0.94 which means that it shows the "high" category, while the calculation of the effect size value in the control class is 0.70 which means it has a "moderate" category. This shows that the problem-solving learning model has a "large" influence on the skills of communicating and mastering the chemistry of students. Based on the results of research that has been done, overall shows that learning using problem-solving learning models has the effectiveness and size of a large influence in improving communication skills and mastery of students' chemistry concept.

\section{CONCLUSION}

Based on the results of research and discussion, be concluded that the model problem solving affects $94 \%$ (large category) in improving the skills of communicating and mastery of students' chemistry concepts. This is supported by the average percentage of times a student activity during learning and teacher's ability to manage the learning categorized as "high", as well as increase pretest-posttest value (n-Gain) on experimental class with the "high" criteria.

\section{ACKNOWLEDGMENT}

First and foremost, we full thankful to Allah SWT and Whole heartedly, we thank our college Universitas Lampung through LPPM.

\section{REFERENCES}

[1] Silberberg, "Principal of General Chemistry" Second Edition, International Edition, New York: Mc. Graw Hill, 2009.
[2] BSNP, "Panduan Penyusunan Kurikulum Tingkat Satuan Pendidikan Jenjang Pendidikan Dasar Dan Menengah", Jakarta, 2006.

[3] Tim Penyusun, Peraturan Menteri Pendidikan dan Kebudayaan Nomor 65 Tahun 2013 Tentang Standar Proses Pendidikan Dasar dan Menengah. Jakarta: Kemendikbud, 2013

[4] K. Suartini, "Pendekatan Dalam proses pembelajaran Matematika dan Sains Dasar", Jakarta: IAIN Indonesia Social Equity Project, 2007.

[5] R.D. Suyanti, "Strategi Pembelajaran Kimia", Yogyakarta: Graha Ilmu, 2010.

[6] F. Octavia, "Efektivitas Problem Solving Pada Materi Larutan Elektrolit-Nonelektrolit Dalam Meningkatkan Keterampilan Berpikir Luwes", Bandarlampung: Universitas Lampung, 2014.

[7] Y. Zuliyanti, "Efektivitas Pembelajaran Menggunakan Lks Berbasis Problem Solving Dalam Meningkatkan Keterampilan Mengkomunikasikan Pada Materi Asam Basa", Bandarlampung: Universitas Lampung, 2017

[8] S. Marfuah, "Efektivitas Problem Solving Untuk Meningkatkan Kemampuan Menyimpulkan Pada Materi Elektrolit Dan NonElektrolit”, Bandarlampung: Universitas Lampung, 2015.

[9] S. Arikunto, "Prosedur Penelitian Suatu Pendekatan Praktik", Rineka Cipta: Jakarta, 2012.

[10] R.R Hake, "Relationship of individual Student Normalized Learning Gains in Mathematics with Gender,High School, Physics, and Pre Test Scores in Mathematics and Spatial Visualization", Physics Education Research Conference, 2002. Tersedia pada : http://www.physics.indiana.edu/ hake/PERC2002h-Hake. pdf .diakses pada tanggal 21 November 2017

[11] S. Dincer, "Effect of Computer Assisted Learning on Students' Achievement in Turkey: a Meta-Analysis". Journal of Turkish Science Education, 2015, vol. 12(1), pp. 99-118.

[12] Lidiawati. 2011. Efektivitas Penerapan Metode Problem Solving Dalam Meningkatkan Keterampilan Mengkomunikasikan dan Penguasaan Konsep Koloid (skripsi).FKIP Unila. Bandarlampung

[13] Y. Carolin, "Penerapan Metode Pembelajaran Problem Solving Dilengkapi LKS Untuk Meningkatkan Aktivitas dan Prestasi Belajar Pada Materi Hukum Dasar Kimia Siswa Kelas X Mia Sma Bhineka Karya 2 Boyolali Tahun Pelajaran 2014/2015", Surakarta: Universitas Negeri Surakarta, 2015.

[14] Z. Iqbal, "Penerapan Model Problem Solving Untuk Meningkatkan Penguasaan Konsep Siswa Pada Materi Asam Basa Arrhenius", Bandarlampung, Univristas Lampung, 2017. 